\title{
Land of Extinct Volcanoes Geopark - geoeducation for everyone
}

\author{
Geopark Kraina Wygasłych Wulkanów - geoedukacja dla każdego
}



${ }^{1}$ The Kaczawskie Association, Mściwojów 45a, 59-407, Poland

piotr@kaczawskie.pl,julia@kaczawskie.pl
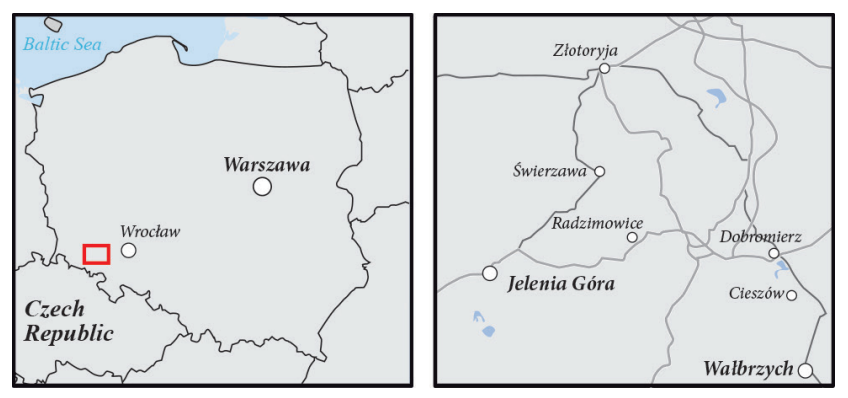

Article history:

Received: 13 November 2020

Accepted: 12 December 2020

Available online: 17 February 2021

(C) 2019 Authors. This is an open access publication, which can be used, distributed and reproduced in any medium according to the Creative Commons CC-BY 4.0 License requiring that the original work has been properly cited.

\begin{abstract}
The Kaczawskie Mountains and Foothills - Geopark Land of Extinct Volcanoes is an area with an extremely interesting geological structure and outstanding landscape values. Great geodiversity makes it possible to prepare a geoeducation offer for practically every recipient - from kids, through adults interested in natural sciences, to natural science students.

The characteristics of the Kaczawskie Mountains and Foothills enable one to develop a nationally unique form of geotourism and utilization of local natural resources for various geoeducation programs. Despite the small area of the mentioned region, it is possible to raise topics related to volcanic phenomena, the formation of mountain ranges, climate change and the impact of glaciers on the relief of the terrain. Educational activity at the Geopark Land of Extinct Volcanoes do not need to be limited only to geological issues, but may also include environmental issues, waste management or even historical topics.

However, apart from the very existence of geotourism attractions, equally important are their uniform promotion and dissemination of knowledge about them. This can be done by describing the most important geopoints in the field, e.g. through a network of educational boards or by organizing promotional field trips. This would increase the knowledge about the geological richness of the described region among tourists and residents. The work of the Kaczawskie Association, which is trying to include the Land of Extinct Volcanoes Geopark in the UNESCO World Geopark Network, is currently heading in this direction. The implementation of this initiative will not only increase the interest in natural sciences and the region, but will also allow it to keep its authentic and unique character. Unfortunately, the process of application to the UNESCO GGN, both the development of the geoeducation and geotourism in the region of the Kaczawskie Mountains and Foothills, has been slowed down by the COVID-19 pandemic.
\end{abstract}

Keywords: The Kaczawskie Mountains and Foothills, geoeducation, geotourism

Treść: Góry i Pogórze Kaczawskie - Geopark Kraina Wygastych Wulkanów to obszar o niezwykle ciekawej budowie geologicznej oraz nieprzeciętnych walorach krajobrazowych. Duża georóżnorodność umożliwia przygotowanie oferty geoedukacyjnej praktycznie dla każdego odbiorcy - od uczniów szkoły podstawowej, przez osoby doroste, aż po studentów kierunków przyrodniczych.

Charakterystyka Gór i Pogórza Kaczawskiego umożliwia unikalny w skali Polski rozwój geoturystyki i wykorzystanie lokalnych zasobów przyrodniczych do różnorodnych programów geoedukacyjnych. Na omawianym fragmencie Sudetów Zachodnich (o powierzchni okoto $1300 \mathrm{~km}^{2}$ ) możliwe jest poruszanie zagadnień dotyczacych m.in. zjawisk wulkanicznych, powstawania łańcuchów górskich, zmian klimatu i wpływu lądolodu na rzeźbę terenu. Tematyka zajęć edukacyjnych w Geoparku Kraina Wygastych Wulkanów nie musi być jednak ograniczona do zagadnień geologicznych i może również obejmować kwestie ochrony środowiska, gospodarki odpadami, a także nawiązywać do tematów historycznych i kulturowych.

Niemniej oprócz samego istnienia walorów geoturystycznych równie istotne jest ich spójne i jednorodne wyeksponowanie i upowszechnianie wiedzy na ich temat. Można tego dokonać, opisując najważniejsze punkty w terenie, np. dzięki sieci tablic edukacyjnych, opracowywaniu i udostępnianiu informacji geoturystycznych w Internecie czy też organizowaniu popularyzatorskich wycieczek terenowych. Pozwolitoby to na zwiększenie wiedzy na temat bogactwa geologicznego opisywanego regionu wśród turystów i mieszkańców. W takim kierunku zmierzaja prace Stowarzyszenia Kaczawskiego, które stara sięo właczenie Geoparku Kraina Wygastych Wulkanów do Światowej Sieci Geoparków UNESCO. 
Piotr Słomski, Julia Jankowska, Ewelina Rozpędowska

Osiagnięcie tego celu przyczyni się nie tylko do wzrostu zainteresowania naukami przyrodniczymi oraz regionem, ale i pozwoli zachować jego autentyczny i wyjątkowy charakter. Niestety zarówno proces aplikacji do Światowej Sieci Geoparków UNESCO, jak i rozwój geoedukacji i geoturystyki w Górach i na Pogórzu Kaczawskim zostat spowolniony przez pandemię COVID-19.

Słowa kluczowe: Góry i Pogórze Kaczawskie, geoedukacja, geoturystyka

\section{Introduction}

The region of the Kaczawskie Mountains and Foothills is also known as Land of Extinct Volcanoes Geopark. This last name is used to promote the unique geological heritage of this part of the Sudetes. The Kaczawskie Mountains and Foothills has an extremely interesting and complicated geological structure and outstanding landscape values. Therefore, this region is ideal for educational activities dedicated to a wide variety of topics in the field of Earth sciences, especially geography and geology.

The great diversity of the geological structure and attractive terrain relief make it possible to prepare a geoeducational offer for every recipient, regardless of age, knowledge, physical condition and experience in tourism.

In the Land of Extinct Volcanoes, even children attending preschool institutions and the first grades of primary school can begin their adventure with natural sciences. Students of higher grades of primary and secondary schools can also develop their knowledge. Adults interested in Earth sciences will be able to find active recreation in the Kaczawskie Mountains and Foothills too. Students of natural sciences such as geography, geology, environmental protection or biology have been attending field exercises for many years in the described region. However, along with the development of the Geopark idea, followed by the preparation and sharing of some less known geopoints, the educational potential of the Kaczawskie Mountains and Foothills will increase and become more diverse.

In this article, we want to present the most important forms of geological and ecological education in the Kaczawskie Mountains and Foothills. We want also to indicate potential directions of development in the field of geoeducation. Special attention will be placed on activities, which are focused on increasing the environmental awareness of tourists and members of local communities, as well as those that can help to preserve the unique character of the region. The activities organized by the Sudetic Educational Centre in Dobków - an educational centre belonging to the Kaczawskie Association, will serve as the examples.

\section{Short geological characteristic}

In the Kaczawskie Mountains and Foothills, over 500 million years of geological history can be traced in the rocks occurring in the region, in a relatively small area. Like the entire Sudetes, the described area has a complicated, even socalled "mosaic" geological structure (Baranowski et al., 1990;
Mazur et al., 2006, 2010; Golonka et al., 2018). In a geological sense, the Kaczawskie Mountains and Foothills are located in the area of two large geological units: the Kaczawa Metamorphic Complex (Kaczawa Unit) and the North Sudetic Synclinorium (Fig. 1).

The Kaczawa Metamorphic Complex is built from a sequence of metamorphosed sedimentary and volcanic rocks that have been metamorphosed at the turn of the Devonian and Carboniferous. The mineral composition of metamorphic rocks and the tectonic structures observed in them indicate that this unit is a fragment of the Variscan accretionary prism (Baranowski et al., 1990; Mazur et al., 2010; Golonka et al., 2018).

The mountains, which had been raised during the Variscan orogeny, soon has been subjected to strong erosion and were a source of material for the first sedimentary rocks formed in the depressions of the metamorphic basement (Baranowski et al., 1990). Additionally, during the Permian, strong volcanic activity took place (Awdankiewicz, 2006). Sedimentation has begun at the end of the Carboniferous and continues till today, however, the sedimentary rocks from the Upper Carboniferous, Permian and Mesozoic seem to be most interesting. Aforementioned sedimentary rocks are represented by rocks formed in various environments (land, river, sea) and a changing climate condition (Milewicz, 1985).

The remains of the youngest volcanic episode, Cenozoic basalts ca. 20-30 million years in age (Birkenmajer et al., 2007) belong to the important geotouristic resources of the Land of Extinct Volcanoes Geopark. These rocks belong to the eastern part of the Central European volcanic province. In the area of the former volcanic field Legnica-ZłotoryjaJawor, you can see the relicts of volcanic processes (Cwojdziński \& Jodłowski, 1982). It is also worth mentioning the interesting glacial sediments, which were deposited in several places in the described region during the last period of the Pleistocene glaciations.

\section{Geoeducation \\ in the Land of Extinct Volcanoes}

Geoeducation can be defined in at least three different ways (Kubaliková et al., 2016): (1) The National Geographic Society proposes to treat geoeducation as a comprehensive education about the mechanisms of nature and human civilization, on a local, regional and global scale; (2) the second approach is limited to the higher education of students in the field of Geosciences; (3) the most common and intuitive understanding of geoeducation refers to the popularization of 
knowledge from various Geosciences among students, tourists and members of local communities. The last approach is the basis of the geoeducational activity of the Kaczawskie Association. Nevertheless, the other two approaches are not neglected, since the Kaczawskie Mountains and Foothills offer geoeducation understood in a holistic way, which make it possible to also see natural sciences in the economic, social and cultural perspective.


Metasedimentary rocks undivided with minor metavolcanic rocks,

locally deformed as mélange



Metamudstones \& clastic limestones

Metabasalts (transitional WP/MORB type), subsidiary metasedimentary rocks

Mélanges: sandstone, claystone, chert

in highly deformed lithic arenite \& mudstone matrix

Mixed metasedimentary

and metavolcanic rocks

$\because \nabla \cdot \square$ Slates with limestone and greenstone blocks a. $\bullet$ in slate matrix - Radzimowice slates

Epi-Variscan cover (undivided)

Fig. 1. Location and geological sketch of study area: A - position of the Bohemian Massif and the Sudety Mountains in the framework of main tectonic units of Europe (RH - Rhenohercynian Zone; MGCR - Mid-German Crystalline Rise; ST - Saxothuringian Zone; TB - Tepla-Barrandian Zone; MO - Moldanubian Zone); B - simplified geological map of the Bohemian Massif with the position of the Kaczawskie Mountains and Foothills; C - generalized geological map of the Kaczawskie Mountains and Foothills, after Baranowski et al. (1990) 


\section{Examples of geoeducational activity in the Land of Extinct Volcanoes}

The valuable and relatively well-preserved diversified natural environment, as well as interesting cultural background of the Kaczawskie Mountains and Foothills make it possible to prepare diverse geotouristic and geoeducational proposals. The topics of conducted educational activities and projects go beyond geology and also concern environmental protection, water management and waste management. Below, we present only selected examples of potential geoeducational activities.

The Ostrzyca hill dominating over the Kaczawskie Foothills is one of the most crucial and recognisable geopoints in the described region (Fig. 2). Sudetic Educational Centre was organising geoeducational trips for children, on the top of Ostrzyca in years 2017-2020. These trips were co-financed by the Lower Silesian Fund for Environmental Protection in Wrocław and were organised in the framework of environmental education programs developed by educators from the Kaczawskie Association.

Ostrzyca is a volcanic neck built of Cenozoic basanites (Szumowska et al., 2013). There is a visible hexagonal (columnar) joint in the rocks on the top of the hill. A trip to Ostrzyca is an opportunity to discuss and learn about the genesis of volcanism, products of volcanic eruptions and potential threats resulting from volcanic eruptions. These issues can be discussed from a broader perspective, global perspective as well as on a local Sudetic scale. It must be mentioned that the educators from the Sudetic Educational
Centre adjusted each time the amount of transferred knowledge to the needs and possibilities of participants. Moreover, the slopes of Ostrzyca are partially covered with rock debris, which was formed as a result of weathering processes in the conditions of a periglacial climate during the last ice age, therefore geomorphology and climate change topics can be discussed here too. The area of the hill is covered by the "Ostrzyca Proboszczowicka" reserve, which protects valuable floristic communities. This in turn makes it easy to extend the content of the courses to botanical issues and forms of nature protection.

It is worth mentioning that most often trips to Ostrzyca were combined with a visiting the municipal waste landfill in the nearby village of Jastrzębnik. The landfill was established in 1993 in the basin of the old basalt quarry, in which mining activities ceased (Fig. $3 \mathrm{~A}$ and B). Over time, a waste reloading station was also opened at that landfill. The participants of our trips could gain knowledge about the principles of waste segregation, the possibilities of their secondary use, as well as the problems that must be faced in landfills, i.e. dangers of a leachate or the need to burn gases generated from waste. Courses were conducted in cooperation with the employees of the facility. The landfill in Jastrzębnik is an ideal example of reusing a closed quarry. Groups visiting this place can learn that storing waste in an old quarry allows you to avoid the creation of heaps of waste in the local landscape and minimize the risk of a harmful leachate. Last, but not least, the former basalt quarry in Jastrzębnik, compared with numerous geological attractions of the region, does not present any outstanding natural value, which makes it even more suitable for practical uses such as a landfill.



Fig. 2. The Ostrzyca hill - a volcanic neck built of Cenozoic basaltoids (basanites). Photo DE2 

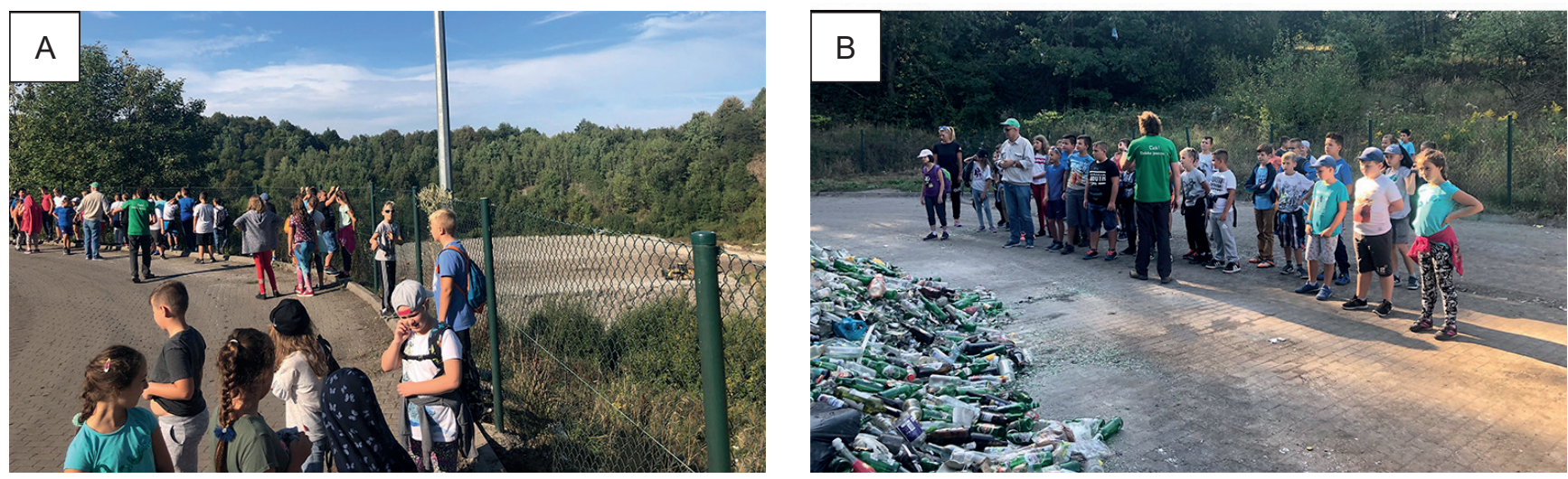

Fig. 3. School trip during classes at the landfill and waste sorting plant in the former basalt quarry nearby the village Jastrzębnik: A - group of students above the landfill in the excavation; B - students at the waste sorting point. Photo J. Jankowska

Geoeducational activities can also be conducted in other closed quarries, which are abundant in the area of the Kaczawskie Mountains and Foothills. These places have a very large geotouristic potential, making it possible to prepare an offer for individual tourists, school groups or those conducting didactic courses with students of natural sciences. Examples of such places include: (1) the inactive rhyolite excavation in the slope of the Wielisławka hill, called the Organy Wielisławskie, (2) the melaphyre quarry in Lubiechowa and (3) the Biały Kamień phyllite quarry in Wojcieszów town (Fig. 4A-C).
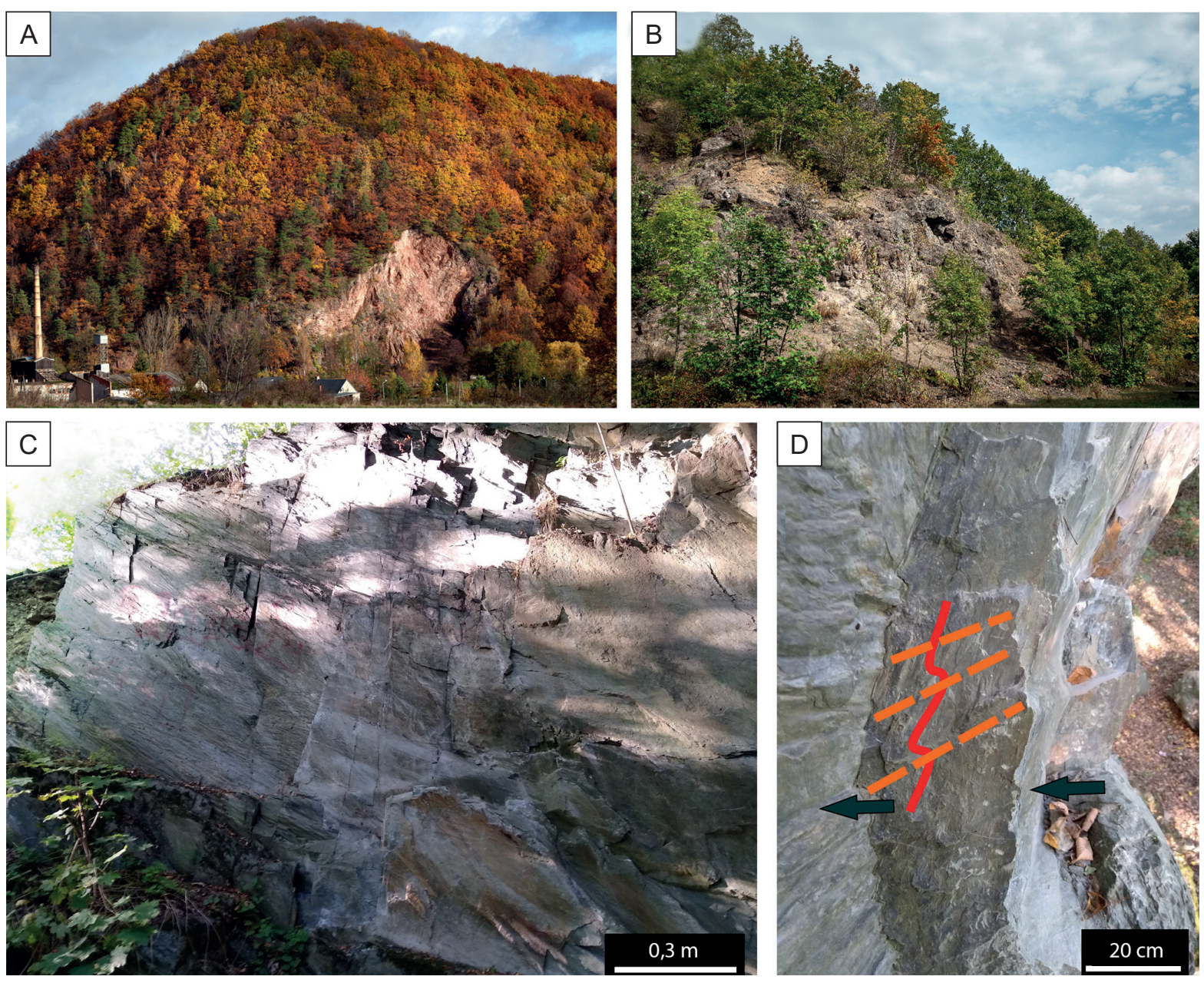

Fig. 4. Selected geological attractions of the Kaczawskie Mountains and Foothills region: A - Wielisławka hill with a visible wall of the Organy Wielisławskie; B - closed melaphyre quarry in the Lubiechowa village; C - northern part of the quarry of phyllites in Wojcieszów town; D - well visible tectonic structures (the surface of the metamorphic foliation is marked with a green arrow, folding - red line, axial plain cleavage - orange lines) in phyllites in Wojcieszów. Photo DE2 (A and B), P. Słomski (C and D) 
The Organy Wielisławskie exposure and the quarry in Lubiechowa are convenient places to tell stories about the volcanic past of the region, with particular emphasis on the Permian volcanic rocks visible in both locations. For more advanced groups, including students, longer classes can be planned in the above-mentioned places, including the recognition and full macroscopic description of the visible rocks. Moreover, at the Organy Wielisławskie exposure, an interesting training using geological compass measurements can be made, due to its unique presence of rhyolitic columns (mostly hexagonal and pentagonal), which have there a radial arrangement (Fig. 4A). Both quarries also are impressive in size (the height of the rock wall on the Organy Wielisławskie reaches up to $50 \mathrm{~m}$ ), which can be visually attractive for all tourists.

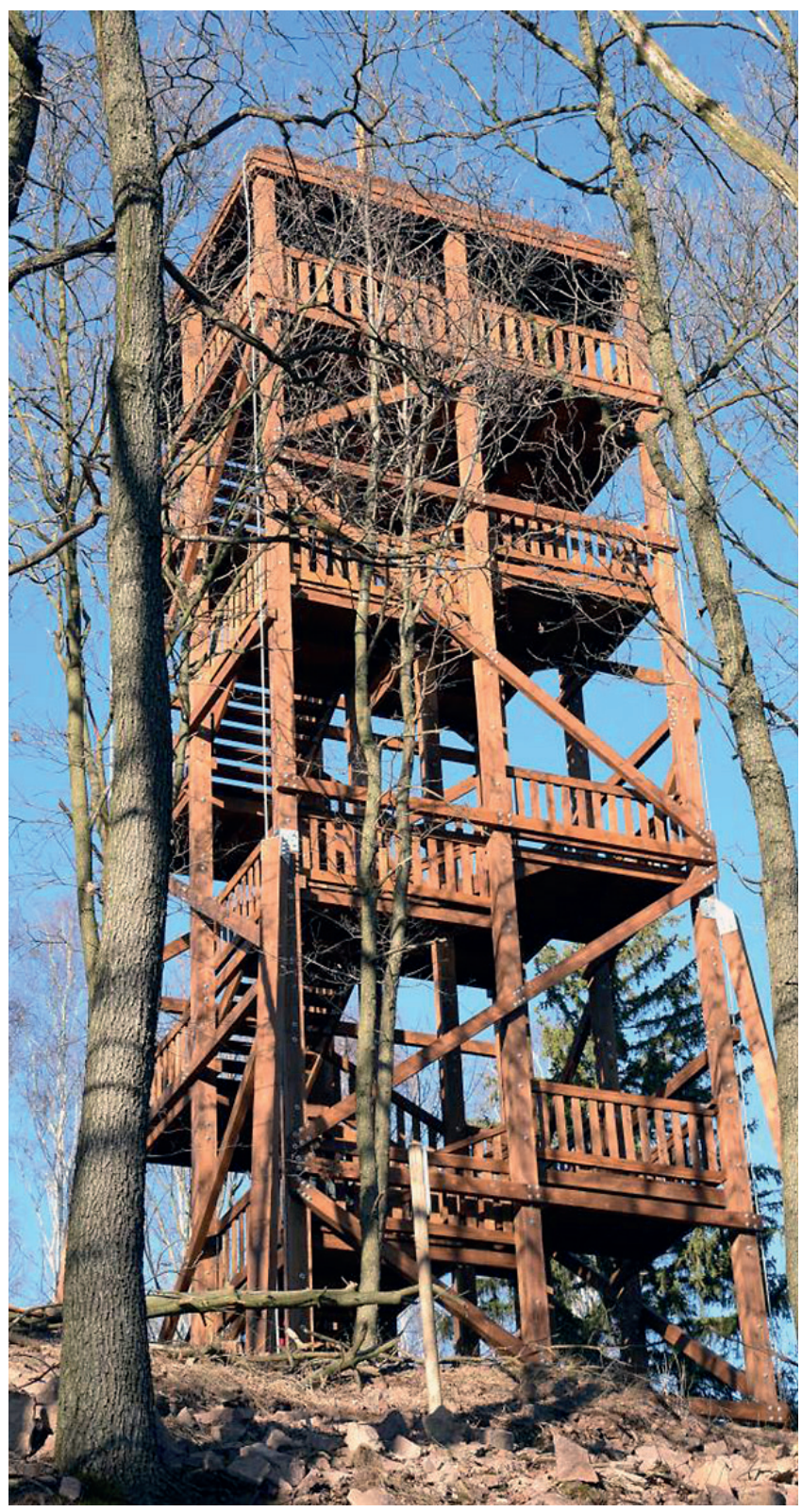

Fig. 5. The viewing tower on the top of the Zawodna Hill. Photo P. Słomski
The Biały Kamień quarry can be a proposal for more inquisitive guests or groups of students. Here you can watch greenstones and phyllites. Particularly interesting is the variety of tectonic structures (folds, metamorphic foliation, and two types of lineation) (Muszer \& Muszer, 2017) visible in the northern part of the excavation, within the phyllites (Fig. 4C). The exposure also shows the structure of boudinage, which is the effect of deformation of layers with different mechanical properties. In this particular case, the greenstones are the more rigid and fragile rock, while the phyllites are the more plastic and deformable layers. However, the most distinct fragment of boudinage in this exposure lies at the base of the wall, after it fell off a few years ago. It is necessary to mention that this exposure is currently widely covered by trees and plants. Unfortunately, graffiti on the rock walls and waste under it are also present.

Another proposition for use of the geoeducational potential of the Kaczawskie Mountains and Foothills are trips to the recently constructed observation towers on the Zawodna (Fig. 5) and Dłużek hills. The first one is located nearby Gozdno village, while the second one is near Wojcieszów town. Visiting the observation towers can be an attractive form of activity for organized groups and individual tourists. In the case of schools groups, the aforementioned viewpoints allow one to address issues of the terrain topography and geomorphological processes. Such a visit can be also a stage of a longer geoeducational trip. Interestingly, the observation towers mentioned above, due to the possibility of viewing a wide panorama, additionally make possible a discussing about issues such as the degree of deforestation, land usage, landscape protection, etc. The towers and their neighbourhood can be also a good place to conduct exercises and field games allowing participants to practice their ability to read maps, use of compass or apply their photography skills.

It seems reasonable that each observation tower should have information board with a description of the visible panorama. Such a table exists in Wojcieszów, but the tower on the Zawodna hill does not have this kind of information facilities. A proposed description of the view from the tower in Gozdno, in the most attractive, south-south-west direction (SSW) is shown in figure 6.

In geoeducation, as in many other activities, the best results can be achieved thanks to the cooperation of various, complementary entities. Examples of such activity were trips to the dry flood reservoir in Świerzawa town, organized for school groups by Sudetic Educational Centre in cooperation with the Lower Silesian branch of the National Water Management Authority. These classes were conducted in years 2017-2020 in the framework of the aforementioned educational programs co-financed by the Lower Silesia Fund for Environmental Protection in Wrocław. 




Fig. 6. The panoramic view from the observation tower on the Zawodna hill from ESE to WNW. The described peaks belongs to three mountain ranges: the Rudawy Janowickie, the Karkonosze (Giant Mountains) and the Kaczawskie Mountains. Photo P. Słomski

A walk along the dam in Świerzawa (Fig. 7) allowed the participants to familiarize themselves with the issues of water circulation in nature, water retention, basics of water chemistry and flood prevention. In the case of older age groups, it was also an opportunity to discuss the construction of the dam itself. Moreover, the vicinity of the dam is extremely attractive for geological reasons. On both sides of the Kamiennik stream, especially on its north side, sedimentary rocks from the turn of the Carboniferous and Permian are exposed (Ostromęcki, 1972; Wojewoda \& Mastalerz, 1989; Solecki, 2011). These rocks are an effective example of the braided river sediments, which were formed in a dry and hot climate. Since that, the vicinity of the dam in Świerzawa makes of possible to conduct courses dedicated to climate change and the genesis and types of rocks.

This outcrop has been less and less accessible in recent years due to strongly developed vegetation. This situation has changed at the end of 2019, when, thanks to the initiative of the Kaczawskie Association, the authorities of Świerzawa decided to clear this geopoint from excess vegetation (Fig. 8). As a result, the potential of this location can be already better utilised, although this is only the first step. The Kaczawskie Association is currently preparing an educational board, which will highlight the geological and hydrological values of this location.

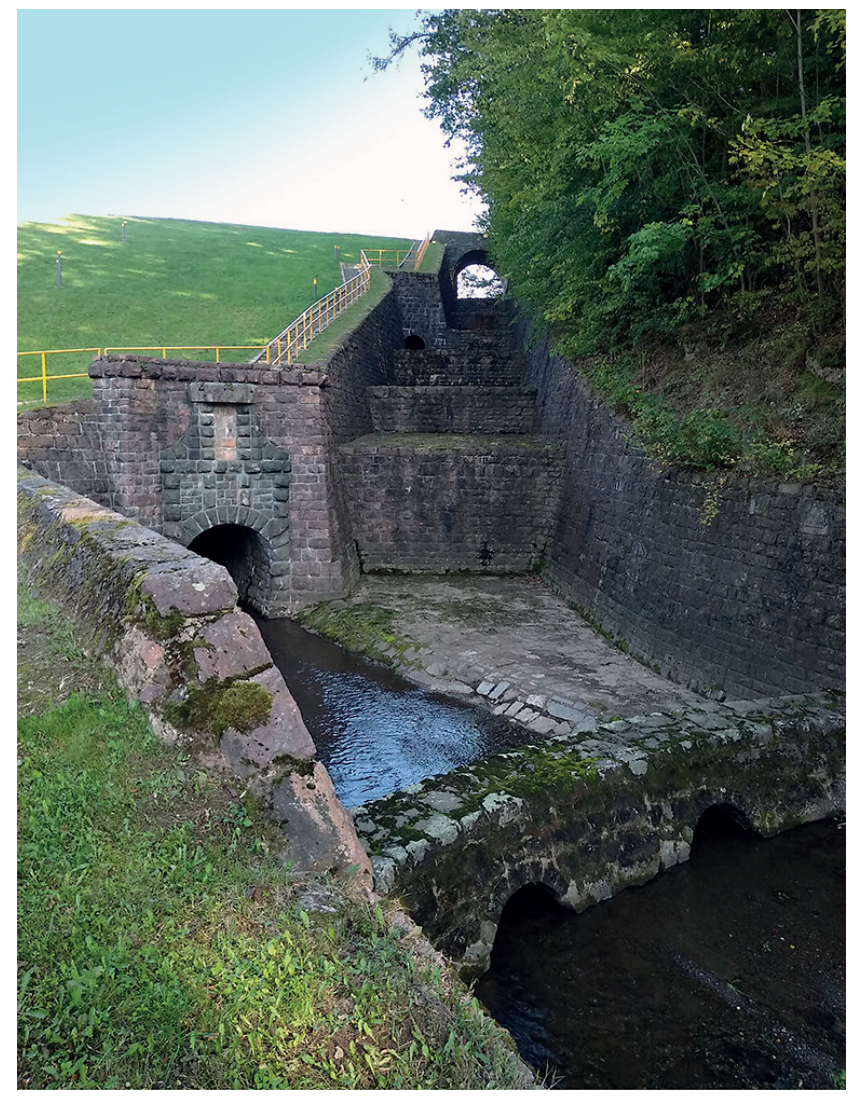

Fig. 7. The dam on the dry flood reservoir in the Świerzawa town. Photo P. Słomski 




Fig. 8. The sediments of the braided river near the dam on the Kamiennik stream in Świerzawa, cleared of excessive vegetation. Three types of sedimentary rocks are visible in the rock wall: A - conglomerates; B - sandstones; C - mudstones. Photo M. Biernat

\section{Geoeducational potential of working quarries}

In the described region, working quarries continue to exist, such as the Wojcieszów limestone quarry in the Połom Mountain massif in Wojcieszów (Fig. 9A) or the Wilcza Góra Basalt Mine on the Wilkołak Hill near Złotoryja. It is important to already consider if and how these objects can be used in terms of geoeducation and geotourism after the end of exploitation.

In both cases, it would be appropriate to install geoeducational tables, informing about the history of exploitation in a given place and providing the geological context. Moreover, these quarries have the potential for creating short educational paths covering a wider range of issues. Additionally, in the quarry on the Połom Mountain in Wojcieszów, there may be a chance for utilising the industrial infrastructure, i.e. the old lime kiln (Fig. 9B), and turning it into the part of the exposition. The kiln should remain in the quarry as an illustration of the old fashioned limestone processing. It would be even more interesting, if the mentioned furnace could also serve as an observation tower located inside the quarry, as long as its technical condition allows for such use. It is also worth mentioning, that all the Wojcieszów limestone outcrops and exposures are very interesting due to the fact that their Cambrian age was confirmed relatively recently, based on Archaeocyaths fossils (Białek et al., 2007).

In case of the Wilcza Gora Basalt Mine (within the Wilkołak hill), the quarry is expected to operate until the year 2027. The investor has prepared the proposition of terrain reclamation, which would include the installation of educational infrastructure at the bottom of the quarry, creation of a geological garden and establishment of a viewing point, as well as a water reservoir (Marek et al., 2014). Although all these propositions are interesting and seem to be a proper way to give a "second life" to the old quarry, we would like to emphasize the need for cooperation with local citizens and touristic organisation in discussing the details of such enterprises. This is important in particular because this quarry is an extraordinary place for geoeducational activities due to the so-called basalt rose, which is the radial system of basaltic columns visible on the quarry wall (Fig. 10A). 

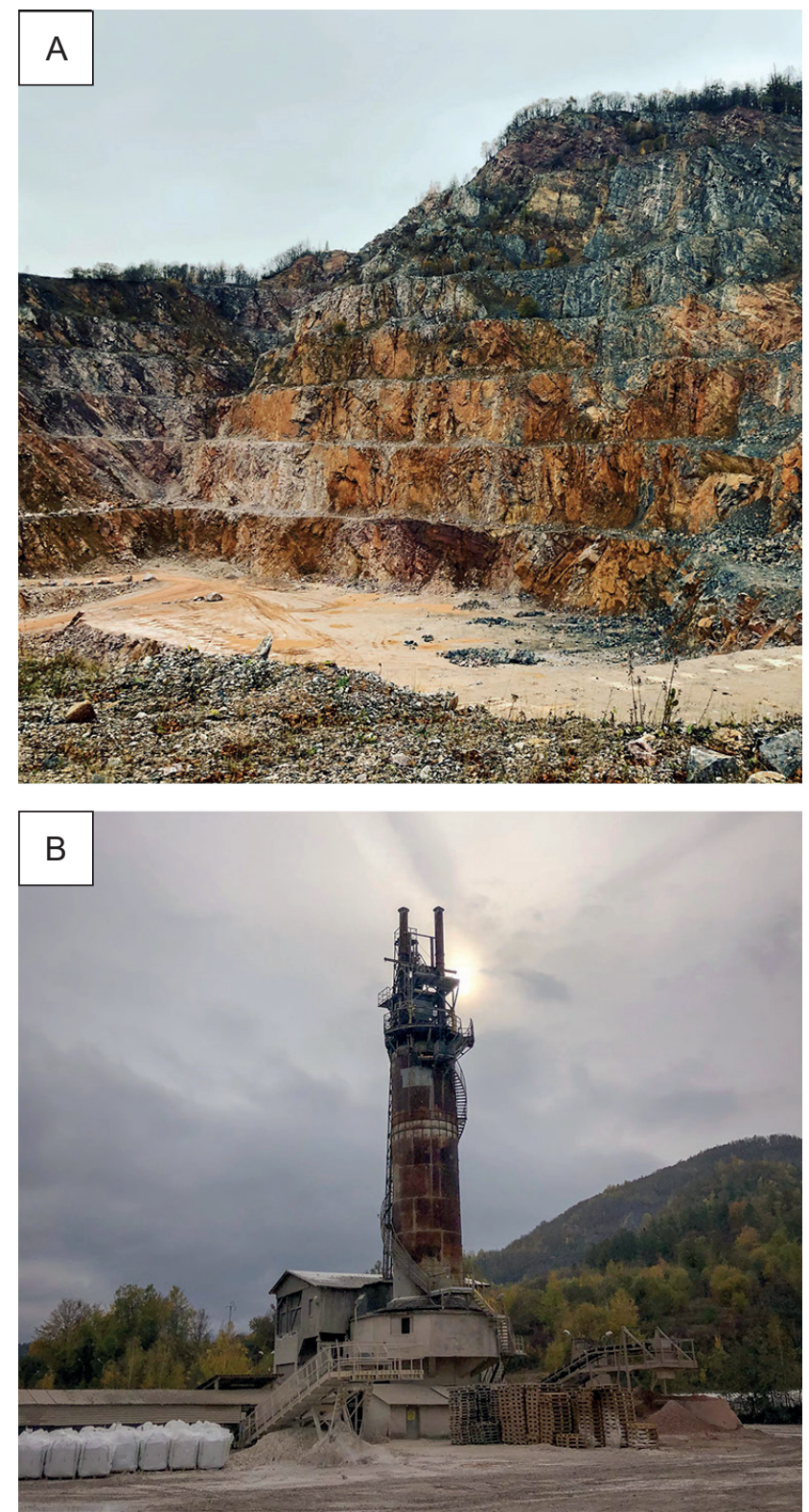

Fig. 9. The quarry of Cambrian Wojcieszów limestones at the slopes of the Połom Mountain in Wojcieszów town: A - a general view of the quarry; B - old lime kiln. Photo J. Jankowska

Another issue for potential discussion may be the location of the viewing point. It is planned to be created on the bottom of the excavation, however, the peak of the hill Wilkołak, due to its isolated character, seems to be a much more attractive location (Fig. 10B). If the top of the hill was cleared of the trees, a $360^{\circ}$ panorama would offer views towards the Kaczawskie Mountains and Foothills, the other nearby Sudetes ranges, the Chojnowska and Legnicka Plains. This would be also a rare opportunity to peek into the depths of the former quarry's excavation. Of course, we are aware, that such a setting for a viewing point would demand additional infrastructure like stairs and barriers, etc., and should be preceded by checking if the hill peak is a safe place for tourists.
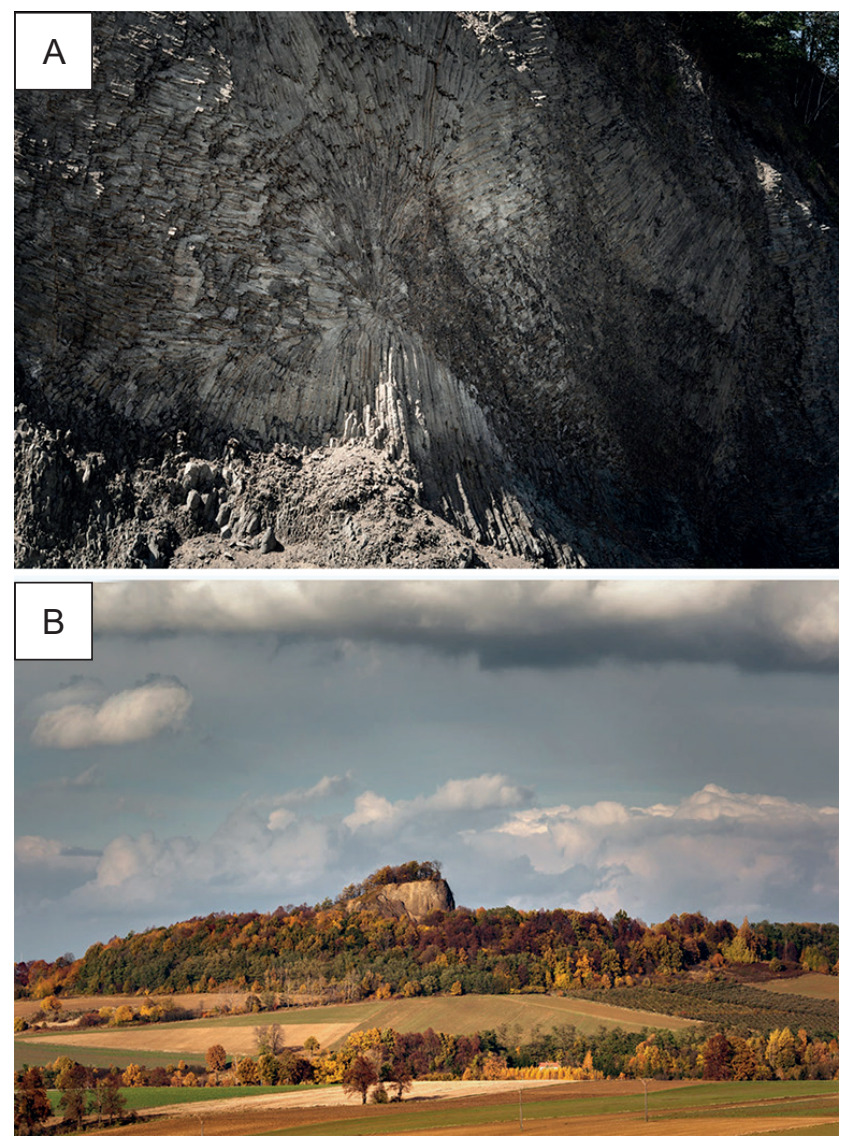

Fig. 10. The quarry of basalt "Wilcza Góra" on the Wilkołak hill: A - the so-called "basalt rose" visible in the wall of the quarry; $\mathrm{B}$ - a view toward Wilkołak hill from south direction. Photo DE2

Interestingly, in the aforementioned quarry, there has been a rockfall in the second half of August 2019, which stopped mining works for some time. According to local media reports, the preliminary findings of the Mining Office in Wrocław suggests that the area of the reserve and its protective pillar were not affected by the rockfall (Kanikowski, 2019). Such events, although rare, at least theoretically may have an impact on further quarry management plans.

\section{Promotion of the region}

\section{and sustainable development of tourism}

The sustainable development of geotourism requires the cooperation of many entities, groups and citizens on a regional scale. The preparation of the geotouristic and geoeducational offer for the potential customers should be combined with the spreading of knowledge about the valuable geological heritage among the local community. This approach will make it possible to activate the entire region around the common goal of geotourism development. 
Another very important thing for geotourism initiatives is the substantive support of the scientific community.

Comprehensive activities for geotourism, and geoeducation development, engaging the local community, have been consistently undertaken in the Kaczawskie Mountains and Foothills for over a dozen years (Pijet-Migoń \& Migon, 2019). In 2002, the Kaczawskie Association, a non-profit organization, was established, and in 2005 the Local Action Group (LAG) "Kaczawskie Partnership" was created. These organizations are acquiring funds and coordinate work on tourist and educational projects in the Kaczawskie Mountains and Foothills region. Thanks to the efforts of the abovementioned entities, the Sudetic Educational Centre was opened in 2015 in the village of Dobków. It is a modern, interactive educational centre, focusing on the geological heritage of the Land of Extinct Volcanoes and education in the field of natural sciences. The Kaczawskie Association is involved in the process of submitting the application for the Land of Extinct Volcanoes Geopark into the UNESCO Global Geoparks Network - GGN. In 2019, a geological inventory of the Kaczawskie Mountains and Foothills was carried out (Inwetaryzacja geopunktów na obszarze Partnerswa Kaczawskiego, 2019) and a system of graphic identification of the region was developed. In December 2019, the Kaczawskie Association submitted a complete application dossier to UNESCO GGN (Land of Extinct Volcanoes Geopark Application Dossier, 2019).

The application to the UNESCO GGN is an example of large-scale activities dedicated to building the prestige of the region, making it possible to protect and promote it internationally. Nevertheless, there are also many local initiatives in the Land of Extinct Volcanoes, aimed to promote the region and encourage tourists to explore it. An example of such an initiative is the program "Passport of the Discoverer of the Land of Extinct Volcanoes", which was launched in 2018. It is both a program of cooperation between local tourist and educational entities and a campaign targeted at tourists. In the Kaczawskie Mountains and Foothills, there are many small family businesses offering workshops prepared for families. Such entities include (apart from Sudetic Educational Centre, which conducts scientific workshops covering mineralogy, climate protection, basic issues of chemistry and physics), numerous ateliers offering creative workshops, e.g. weaving, ceramics, glass engraving, herbalism or gold rinsing. All of the mentioned activities intensely refer to the historical, cultural and natural heritage of the Kaczawskie Mountains and Foothills. Thanks to the cooperation of all educational entities, as well as restaurants and accommodation facilities, before the periods of increased tourist traffic, such as holidays or long weekends, a coherent program of workshops is developed, which is then promoted together. Throughout the year, for participation in each workshop, visitors receive dedicated stamps or stickers for visiting attractive places (volcanic rock outcrops, medieval castles, historic city centres). The stamps entitle them to be awarded with medals created by local artists and craftsmen. This approach mobilizes tourists to explore the Kaczawskie Mountains and Foothills, and at the same time creates an opportunity for establishing contacts with the local community. Importantly, all offered workshops have sufficiently high substantive levels, thanks to the fact that the offered product is both authentic and professional, and also has an educational character.

\section{The impact of COVID-19 pandemic on geotourism in the region}

This paper was planned to be dedicated only to geoeducation, however, in the face of recent months, we think that we should add a short paragraph referring to COVID-19 pandemic and its impact on the geotourism in the Kaczawskie Mountains and Foothills.

We will use the statistical data referring to the number of visitors in the Sudetic Educational Centre as an example. We believe, that this data are, at least to some extent, representative also for other educational entities in the Land of Extinct Volcanoes Geopark, since many groups and tourists visit not only Sudetic Educational Centre, but also other places.

We will present and shortly compare data from 2017 to 2020, each time only from January to September for consistency. During a few recent years, the total number of visitors, who had been visiting Sudetic Educational Centre from January to September, was constantly growing, from ca. 9525 in September 2017 to ca. 13509 in September 2019 (Fig. 11). Moreover, the share of organised groups was getting bigger in each of these years, from 54\% in September 2017 to $65 \%$ in September 2019 (Fig. 11).

The year 2020 has brought two important changes. First of all, the number of visitors till September decreased ca. $290 \%$ in comparison to the previous year and was equal to ca. 4678 . Secondly, individual guests $(58 \%)$ were prevailing over organised groups (42\%). This was caused by the "lockdown" in springtime and the lack of school trips in that time. When we focus only on the holiday months (July and August in Poland) the proportions between individual visitors and groups are similar to the previous years, although the total number of guests was ca. 900 less than in holiday $2019(-33 \%)$. This suggests, that the mobility of potential tourists was reduced due to all the negative effects of the pandemic. Moreover, the assumption that people will spend their holiday in Poland instead of going abroad, was false. Unfortunately, since the end of October 2020, the Sudetic Educational Centre is temporarily closed, which is related to the restrictions during the second wave of the pandemic. 




Fig. 11. The number of visitors in Sudetic Educational Centre during last four years (data from January to September for each year)

\section{Summary}

The regions with rich nature and historical heritage are predestined to play an important educational role, both in terms of school education and various forms of non-formal education. Nevertheless, even the greatest tourist attraction will not contribute itself to the increase of ecological awareness of tourists and local communities, unless educational and touristic entities develop a cooperative network. Such a network can guarantee the creation of a valuable educational and geotouristic offer for a vast range of receivers. The educational activities presented in this text provide examples of efforts to strengthen the sustainable development of tourism and geoeducation, taking into account the local specificity of the region.

2020 is a very special year in geotourism and geoeducation in the Kaczawskie Mountains and Foothills. The COVID-19 pandemic changed the volume and structure of the tourist traffic and slowed the process of application to the UNESCO GGN. However, all the local parties, including the Kaczawskie Association, are ready to restart the realisation of their educational enterprises, as soon as it will be possible.

\section{References}

Awdankiewicz M., 2006. Fractional crystallization, mafic replenishment and assimilation in crustal magma chambers: geochemical constraints from the Permian post-collisional intermediate-composition volcanic suite of the North-Sudetic Basin (SW Poland). Geologia Sudetica, 38: 39-61.

Baranowski Z., Haydukiewicz A., Kryza R., Lorenc S., Muszyński A., Solecki A. \& Urbanek Z., 1990. Outline of the geology of the Góry Kaczawskie (Sudetes, Poland). Neues Jahrbuch für Geologie und Paläontologie, 179: 223-257.

Białek D., Raczyński P., Sztajner P. \& Zawadzki D., 2007. Archeocjaty wapieni wojcieszowskich. Przegląd Geologiczny, 55(12/2): 1112-1116.

Birkenmajer K., Pécskay Z., Grabowski J., Lorenc M.W. \& Zagożdżon P., 2007. Radiometric dating of the Tertiary volcanics in Lower Silesia, Poland. V. K-ar and palaeomagnetic data from late Oligocene to early Miocene basaltic rocks of the north-sudetic depression. Annales Societatis Geologorum Poloniae, 77(1): 1-16.
Cwojdziński S. \& Jodłowski S., 1982. "Plamowe" koncentracje bazaltowe Masywu Czeskiego i Dolnego Śląska. Biuletyn Instytutu Geologicznego, 341: 201-222.

Golonka J., Barmuta M. \& Barmuta J., 2018. Kaczawa Klippen Belt - geotouristic attraction in the Sudety Mountains, SW Poland. Acta Geoturistica, 9(1): 30-35. https://doi.org/10.1515/agta2018-0004.

Inwentaryzacja geopunktów na obszarze Partnerstwa Kaczawskiego, 2019. https://www.gorykaczawskie.pl/do-pobrania/ [accessed: 2020.12.16].

Kanikowski P., 2019. WUG: rezerwat Wilcza Góra nie został naruszony. https://24legnica.pl/wug-rezerwat-wilcza-gora-nie-zostal-naruszony/ [accessed: 2020.12.16].

Kubaliková L., Bajer A. \& Kirchner K., 2016. Secondary geodiversity and its potential for geoeducation and geotourism: a case study from Brno city. Public recreation and landscape protection, 224-231.

Land of Extinct Volcanoes Geopark Application Dossier, 2019. https:// www.gorykaczawskie.pl/do-pobrania/ [accessed: 2020.12.16]. 
Piotr Słomski, Julia Jankowska, Ewelina Rozpędowska

Marek P., Patla S. \& Rogosz K., 2014. Projektowanie rekultywacji na przykładzie kopalni Wilcza Góra. Mining Science, 21, Special issue 1: 151-158.

Mazur S., Aleksandrowski P., Kryza R. \& Oberc-Dziedzic T., 2006. The Variscan Orogen in Poland. Geological Quarterly, 50(1): 89-118.

Mazur S., Aleksandrowski P. \& Szczepański J., 2010. Zarys budowy i ewolucji tektonicznej waryscyjskiej struktury Sudetów. Przeglą Geologiczny, 58(10): 133-145.

Milewicz J., 1985. A proposal of formal stratigraphic subdivision of the infill of the North Sudetic Depression. Przeglad Geologiczny, 33: $359-389$.

Muszer J. \& Muszer A., 2017. Evaluation of the geotouristic attractions from the Wojcieszów area. Geotourism, 1-2: 31-46.

Ostromęcki A., 1972. Profil litostratygraficzny permo-karbonu w zachodniej części Rowu Świerzawy. Geologia Sudetica, 6(1):293-306.
Pijet-Migoń E. \& Migoń P., 2019. Promoting and interpreting geoheritage at the local level - bottom-up approach in the Land of Extinct Volcanoes, Sudetes, SW Poland. Geoheritage, 11(4): 1227-1236. https://doi.org/10.1007/s12371-019-00357-2.

Solecki A., 2011. Rozwój strukturalny epiwaryscyjskiej pokrywy platformowej w obszarze synklinorium północnosudeckiego. In: Żelaźniewicz A., Wojewoda J., Ciężkowski W. (red.), Mezozoik i kenozoik Dolnego Ślaska. Przewodnik 81 Zjazdu PTG, 19-36.

Szumowska M.,Awdankiewicz M. \& Christiansen E., 2013. Geology and petrology of Cenozoic volcanic rocks of Ostrzyca Hill in the Kaczawa Foothills, SW Poland. Mineralogia - Special Papers, 41: 88.

Wojewoda J. \& Mastalerz K., 1989. Ewolucja klimatu oraz allocykliczność i autocykliczność sedymentacji na przykładzie osadów kontynentalnych górnego karbonu i permu w Sudetach. Przegląd Geologiczny, 432, 173-180. 